\title{
Novel Glitazones Reverses Hyperglycemia In STZ Induced Hyperglycaemic Rat Model
}

\author{
Chandan HIRENALLURE MAHESHWARAPPA* (D), Krishna KAMSAGARA \\ LINGANNA $^{* *_{0}}$ D , Prashanth Kumar BOMMENAHALLI REVANAPPA ${ }^{* * *}$ (D), Seema \\ MEHDI $^{* * * *}$ (D), Shreyas AYACHIT ${ }^{* * * * *}$ (D), Suman SUMAN ${ }^{* * * * *}$ (D), Nandini HITTANAHALLI \\ SHIVAKUMAR $^{* * * * * *}$ (D), Sneha DESAI ${ }^{* * * * * * *}$ (D), Swerna ESWARAN
}

Novel Glitazones Reverses Hyperglycemia In STZ Induced Hyperglycaemic Rat Model

\section{SUMMARY}

Diabetes mellitus is the most common chronic metabolic disorder characterized by reduced secretion of insulin or sensitivity to the insulin. It is also a disease of inadequate control of glucose levels in the blood plasma. The present study was formulated to assess the novel glitazones for hypoglycaemic activity in STZ induced rat model. Before in-vivo studies, thirty-two virtual compounds of novel glitazones were subjected to the molecular docking study. The docking study showed that, the compounds $C 5$ and $C 22$ showed the better binding activity with the target protein 3CS8. The acute toxicity studies were done on female rats using OECD guideline 425. No mortality observed at $300 \mathrm{mg} / \mathrm{kg}$ per $\mathrm{kg}$ body weight and based on this result, the dose for in-vivo studies was chosen. The compounds C5 and C22 were evaluated for the hypoglycaemic activity at 10 and $20 \mathrm{mg} / \mathrm{kg}$ body weight in STZ induced hyperglycaemic rats. The compound $\mathrm{C} 5$ at both the dose $(10 \mathrm{mg}$ and $20 \mathrm{mg} / \mathrm{kg}$ ) showed the better activity than C22, where as C22 exhibited better activity at higher dose when tested. The activity was assessed by behavioural and biochemical parameters, on 0th ,7 th, 14 th and 21st day. The study duration was three weeks, on 21st day, the animals were sacrificed and biochemical estimations were done. The compound C5 showed significant activity when compared with C22. The current findings gives a lead for further research to prove the hypoglycaemic activity of novel glitazones at molecular level by employing some more research models.

Key Words: Molecular docking, PPAR $\gamma$, glitazones, diabetes, 3CS8, lipid profile.

\author{
Yeni Glitazonların, STZ ile İndüklenmiş Hiperglisemik Sıçan \\ Modelinde Hiperglisemiyi Tersine Çevirmesi
}

$\ddot{O} Z$

Diabetes mellitus, insülin salgzlanmasının veya insüline duyarlilğgın azalmast ile karakterize edilen en yaygin kronik metabolik hastalıktır. Ayn zamanda plazmada glukoz seviyelerinin yetersiz kontrolü hastalığıdır. Bu çalı̧smada, yeni glitazonların, STZ ile indüklenmis hiperglisemik sıçanlardaki hipoglisemik aktiviteleri değerlendirildi. In vivo çalışmalardan önce, 32 adet yeni glitazonun moleküler yerleştirme çalışması gerçekleștirildi. Moleküler yerleştirme çalışması, C5 ve C22 bileşiklerinin hedef protein 3CS8 ile daha iyi bağlandığın gösterdi. Akut toksisite çalışmaları, OECD kılavuzu 425 kullanularak dişi farelerde yapıldı. Bileşikler, sıçanlarda test edildiğinde $300 \mathrm{mg}$ I kg'da mortalite göstermedi. Bu nedenle in vivo çalışmalar için bu doz seçildi. C5 ve C22 bileşiklerinin hipoglisemik aktiviteleri, 10 ve $20 \mathrm{mg} / \mathrm{kg}$ konsantrasyonda, STZ ile indüklenmiş hiperglisemik sıçanlarda değerlendirildi. Her iki dozda da $(10 \mathrm{mg}$ hem de $20 \mathrm{mg}$ / kg) bileşik C5, C22'den daha iyi bir aktivite gösterdi, C22 daba yüksek dozda daha iyi bir aktivite sergiledi. Aktivite 0, 7, 14 ve 21. gününde davranıssal parametreler, plazma kan glukoz seviyesi ile değerlendirildi. Çalışma süresi üç hafta olup, 21. günde, hayvanlar sakrifiye edildi ve biyokimyasal analizler yapuld. Bileşik C5, C22 ile karşılaştırıldığında önemli bir aktivite gösterdi. Yeni glitazonların hipoglisemik aktivitesini ispatlamak için daha fazla araştırma gerekmektedir.

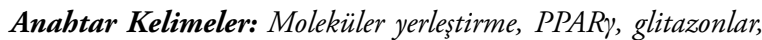
diyabet, 3CS8, lipit profili.

"ORCID: 0000-0003-2395-2699, Department of Pharmacology, JSS College of Pharmacy, JSS Academy of Higher Education \& Research, Mysuru -570015, Karnataka India " ORCID: 0000-0001-7538-0798, Department of Pharmacology, JSS College of Pharmacy, JSS Academy of Higher Education \& Research, Mysuru -570015, Karnataka India -.. ORCID: 0000-0001-9503-741X, Department of Pharmaceutical Chemistry, JSS College of Pharmacy, JSS Academy of Higher Education \& Research, Mysuru -570015, Karnataka India

-... ORCID: 0000-0002-3212-0774, Department of Pharmacology, JSS College of Pharmacy, JSS Academy of Higher Education \& Research, Mysuru -570015, Karnataka India

.... ORCID: 0000-0002-7662-4413, Department of Pharmacology, JSS College of Pharmacy, JSS Academy of Higher Education \& Research, Mysuru -570015, Karnataka India ...... ORCID: 0000-0003-0977-4953, Department of Dravyaguna, Govt. Ayurvedic Medical College \& Hospital, New Sayyajiroa Raod, Mysuru-570001, Karnataka, India

*..... ORCID: 0000-0003-0750-6373, Department of Pharmacology, JSS College of Pharmacy, JSS Academy of Higher Education \& Research, Mysuru -570015, Karnataka India

....... ORCID: 0000-0001-7063-4728, Department of Pharmacology, JSS College of Pharmacy, JSS Academy of Higher Education \& Research, Mysuru -570015, Karnataka India

.munu ORCID: 0000-0003-1185-4442, Department of Pharmacology, JSS College of Pharmacy, JSS Academy of Higher Education \& Research, Mysuru -570015, Karnataka India 


\section{INTRODUCTION}

Diabetes mellitus (DM) is the most common endocrine disorder, which is resulted in resistance to the endocrine gland as a key feature in the development of the disease (Mukhtar, 2019). It is characterized by insulin deficiency or either reduced sensitvity to insulin. About 422 million people in a world are suffering from DM i e. about 70\%, 90\% of these patient's aetiology leads to cardiac dysfunction (Frier, 2014). Because of increased blood glucose levels, different deficiencies are caused and physiological alterations in the nervous system are occured. Globally, the occurrence of diabetes in 2000 and 2030 was predicted to be $2.8 \%$ and $4.4 \%$ respectively. The overall number of diabetes sufferers worldwide is expected to grow from 171 million to 366 million in 2030. And the world's human population appears to be in the midst of a diabetes epidemic (Zheng, 2018).

Many classes of oral hypoglycaemic drugs are available for the treatment of diabetes, among these, glitazones have shown better activity in resistance cases (Davis, 2012). There is a need for developing novel glitazone(s) as promising therapeutics to take care of resistance cases of diabetes. With this context, the present study was conceptualized to evaluate the novel glitazones for possible hypoglycaemic activity using in-vitro and in-vivo animal model.

Glitazones are the class of thiazolidinedione drugs, which act on the nuclear receptor of the Peroxisome Proliferator Activated Receptor Gamma (PPAR $\gamma$ ), which are mainly expressed in adipocytes, liver and skeletal muscle (Mal, 2020). Glitazones belong to oral hypoglycaemic agents and they are used in the treatment of type II DM in adults to enhace the hypoglyceamic activity of other drugs. The activation of PPAR- $\gamma$ affects the insulin sensitivity genes resulting in various metabolic changes like glucose regulation leading to increased insulin sensitivity and glucose uptake, lipid metabolism along decreased gluconeogenesis (Mohammed, 2018).

The molecular docking technique can be used to model atomic level relationship between a small molecule and target protein. This will helps to know the actions of small molecules in the target protein binding site and to elucidate basic biochemical processes (Meng, 2011). The docking process includes two basic steps: determination of the ligand conformation and its position; orientation within docking sites (usually referred to as pose) which measures the binding affinity. In the present study an effort was made to see the binding interaction of 32 virtual compounds with the target protein 3CS8 [PPAR $\gamma$ to PGC-1 $\alpha$ ] (Lionta, 2014).

\section{MATERIAL AND METHODS}

\section{Molecular Docking Studies}

In the present study 3 CS8 was selected as a target protein, with which the ligands interact and finally, the docking pose were visualized. The main docking operation was performed on "DOCK LIGAND" wizard, under SYBYL X 2.1.1 SOFTWARE Package. The active site of the protein was identified by "PROTOMOL GENERATION" Wizard and the ligands were docked along with the co-crystallized ligand which was present within the crystal structure of protein molecule, finally, the binding poses were observed and docking score was obtained (TOTAL SCORE, CRASH SCORE, POLAR SCORE) by using SYBYLX2.1.1 scoring function (Lohning, 2017). RMSD value of re-docked crystal ligand was found to be 0.981

\section{Animals}

The efficacy study was done on Wistar Albino rats procured from The Committee for the Purpose of Control and Supervision of Experiments on Animals (CPSCEA) registered breeder Biogen, Laboratory Animal Facility, Bangalore. The animal handling 
and care were done as per CPCSEA guidelines and Institutional Animal Ethics Committee (IAEC) approval was obtained (Approval no JSSCPM/ IAEC/333/2019) before commencement of the study.

\section{Acute oral toxicity test}

The acute oral toxicity was done as per OECD guideline 425 (Organisation for Economic Cooperation and Development, 2008). By review of literature, it was found that the $\mathrm{LD}_{50}$ of the glitazone derivatives is more than $2000 \mathrm{mg} / \mathrm{kg}$, hence the starting dose of $300 \mathrm{mg} / \mathrm{kg}$ was choosen for acute oral toxicity test. Even the maximum dose of novel glitazones tested in efficacy study was $20 \mathrm{mg} / \mathrm{kg}$ body weight, so more than ten times that of maximum dose tested for any mortality for both the novel compound.

\section{Hypoglycaemic activity}

Wistar Albino Rats weighing between 200-250 $\mathrm{g}$ were divided into seven groups of 8 animals each; treatment and evaluation was done as shown in the Table 1. The induction of hyperglycemia was done by STZ administration as per the standard protocol with slight modification (Graham, 2011). Overnight fasted animals were given a single dose of $50 \mathrm{mg} / \mathrm{kg}$ intraperitoneal (i.p.) injection of STZ. About 15 minutes before administration of STZ, 40 $\mathrm{mg} / \mathrm{kg}$ nicotinamide was given in a single shot by i.p. route (Yoshino, 2018). To avoid drug-induced hyperglycaemic shock, 5\% D-glucose was given for 24 hrs. After $72 \mathrm{hrs}$ of STZ administration, body weight and plasma blood glucose levels were recorded. Animals with 300 to $600 \mathrm{mg} / \mathrm{dl}$ levels of blood glucose were considered as hyperglycaemic and included in the study.

Level of blood glucose was measured with a portable glucometer (ON CALL PLUS) before induction, i.e. on day 0 , and on $7^{\text {th }}, 14^{\text {th }}$ day, $21^{\text {st }}$ day. Samples of blood were collected from each rats using tail vein puncture and blood drops were placed on the blood glucose strips mounted in the blood glucose determination unit.

Animals were euthanized at the end of the experiment; blood samples were collected by carotid bleeding and kept aside for 30 minutes to clot. The clotted blood was centrifuged at $3000 \mathrm{rpm}$ for 10 minutes to collect the supernatant serum. Serum was used for the estimation of the serum glutamate oxaloacetate transferase (SGOT), serum glutamicpyruvic transaminase (SGPT), low density lipoprotein (LDL), high density lipoprotein (HDL), triglycerides (TG), total cholesterol (TC) and glucose by using diagnostic kits (SPINREACT).

Table 1. Study protocol for protective effect of novel glitazones against STZ Rat model.

\begin{tabular}{|c|c|c|}
\hline Group & Treatment & Evaluation \\
\hline Normal & Vehicle & \multirow{7}{*}{$\begin{array}{l}\text { Parameters assessed } \\
\text { 1. Body weight. } \\
\text { 2. } \\
\text { Blood glucose estimation on glucometer on } 0^{\text {th }}, 7^{\text {th }}, 14^{\text {th }} \text { and } 21^{\text {st }} \text { day } \\
\text { 3. Serum lipid profile TG, LDL TC \& HDL. } \\
\text { 4. Serum GOT and GPT } \\
\text { 5. Histopathology }\end{array}$} \\
\hline Control & Vehicle + STZ in the i.p. route & \\
\hline Standard & Vehicle + STZ + Pioglitazone & \\
\hline C5 dose 1 & STZ + novel glitazones low dose10mg/kg & \\
\hline C5 dose 2 & STZ + novel glitazones high dose $20 \mathrm{mg} / \mathrm{kg}$ & \\
\hline C22 dose 1 & $\mathrm{STZ}+$ novel glitazones low dose $10 \mathrm{mg} / \mathrm{kg}$ & \\
\hline C22 dose 2 & STZ + novel glitazones high dose $20 \mathrm{mg} / \mathrm{kg}$ & \\
\hline
\end{tabular}




\section{Histopathology of pancreas}

The rats were given ketamine/xylazine anaesthesia, and the pancreas tissues were extracted, fixed in $10 \%$ phosphate-buffered formalin, and embedded in molten paraffin. Hematoxylin and eosin (H and $\mathrm{E})$ were used to stain the paraffin-embedded blocks with a $5 \mathrm{~m}$ thickness, and the Ishak score was used to score and grade them.

\section{Statistical calculation}

All the results are expressed as Mean \pm SEM, statistical calculations were done using GraphPad Prism free software (GraphPad Software LLC., 2020), $\mathrm{p}$ value less than 0.05 was considered as significant.

\section{RESULTS AND DISCUSSION}

\section{Molecular Docking}

From the Brookhaven protein data bank (www. rcsb.org) the crystallographic data of the enzyme was downloaded and used for the docking studies. Simulation of molecular docking was performed primarily to differentiate the interactions of the simple ligand. In the present study we have selected the target protein 3CS8 with which the ligands were interacted and finally the docking poses were visualised. The docking study reveals that novel compounds C5 and C22 (Table 2, Figure 1) showed a better interaction when compared with that of reference ligand rosiglitazone. Out of 32 virtual compounds, compound C5 and C22 showed better binding interaction. These two novel compounds were selected for hypoglycaemic activity on STZ rat model. The binding interactions include one hydrogen bond with Tyr473 and several hydrophobic contacts with Ile281, Cys285, Ile326, Ile341, Met348, Met364, His449 from arm-I and arm-II of the ligand binding domain (LBD) of PPAR $\gamma$. Thus possibly any PPAR- $\gamma$ binding with His323, Tyr327, His449, and Tyr473 from arm-I of the LBD of PPAR- $\gamma$ has transactivation activity. (Figure 2).

Table 2. Molecular docking results of novel glitazones legends

\begin{tabular}{|c|c|c|c|c|}
\hline SL. No & Novel Derivatives & Total Score & Crash & Polar \\
\hline 0 & Standard Rosiglitazone & 6.7228 & -3.5310 & 1.4621 \\
\hline 1 & $\mathrm{C05}$ & 6.8118 & -2.4301 & 1.5739 \\
\hline 2 & $\mathrm{C22}$ & 6.3202 & -0.9233 & 2.4394 \\
\hline 3 & $\mathrm{C} 23$ & 5.9689 & -2.2540 & 1.7007 \\
\hline 4 & $\mathrm{C} 08$ & 5.9223 & -1.4271 & 1.2935 \\
\hline 5 & $\mathrm{C} 10$ & 5.8397 & -2.4710 & 0.5369 \\
\hline 6 & C09 & 5.7256 & -1.0092 & 0.5791 \\
\hline 7 & $\mathrm{C} 02$ & 5.7248 & -1.1441 & 1.4199 \\
\hline 8 & $\mathrm{C} 26$ & 5.7137 & -1.5412 & 0.5950 \\
\hline 9 & $\mathrm{C} 14$ & 5.6079 & -2.9680 & 1.0689 \\
\hline 10 & $\mathrm{C} 21$ & 5.3159 & -0.9126 & 0.4950 \\
\hline 11 & $\mathrm{C} 01$ & 5.1746 & -1.0141 & 0.6483 \\
\hline 12 & C31 & 5.1738 & -1.6236 & 0.0036 \\
\hline 13 & $\mathrm{C} 20$ & 5.1379 & -0.8814 & 0.5482 \\
\hline 14 & $\mathrm{C} 24$ & 5.1212 & -2.2886 & 2.3748 \\
\hline 15 & C15 & 4.8559 & -2.2510 & 1.0293 \\
\hline 16 & $\mathrm{C} 28$ & 4.7853 & -2.3310 & 0.0009 \\
\hline 17 & C07 & 4.7790 & -3.2454 & 0 \\
\hline 18 & $\mathrm{C} 03$ & 4.6589 & -1.2578 & 0.6321 \\
\hline 19 & C30 & 4.6435 & -1.9447 & 0.5121 \\
\hline 20 & C32 & 4.5504 & -1.4171 & 0.9860 \\
\hline 21 & $\mathrm{C} 06$ & 4.5443 & -1.4067 & 0.5349 \\
\hline 22 & $\mathrm{C} 13$ & 4.5229 & -2.1519 & 0.0037 \\
\hline 23 & $\mathrm{C} 27$ & 4.5101 & -1.0806 & 0.0001 \\
\hline 24 & $\mathrm{C} 17$ & 4.4375 & -2.9890 & 0.0003 \\
\hline 25 & $\mathrm{C} 18$ & 4.4176 & -2.4296 & 0.0013 \\
\hline 26 & $\mathrm{C} 25$ & 4.3999 & -1.3049 & 0.4670 \\
\hline 27 & C29 & 4.2423 & -1.4819 & 0.0005 \\
\hline 28 & $\mathrm{C} 12$ & 4.2317 & -1.5827 & 1.0427 \\
\hline 29 & C16 & 4.2228 & -2.8222 & 0.0003 \\
\hline 30 & C11 & 4.0333 & -1.4412 & 0.0003 \\
\hline 31 & C19 & 3.8878 & -1.1232 & 0.9169 \\
\hline 32 & $\mathrm{C} 04$ & 3.8789 & -3.2460 & 0.0076 \\
\hline
\end{tabular}



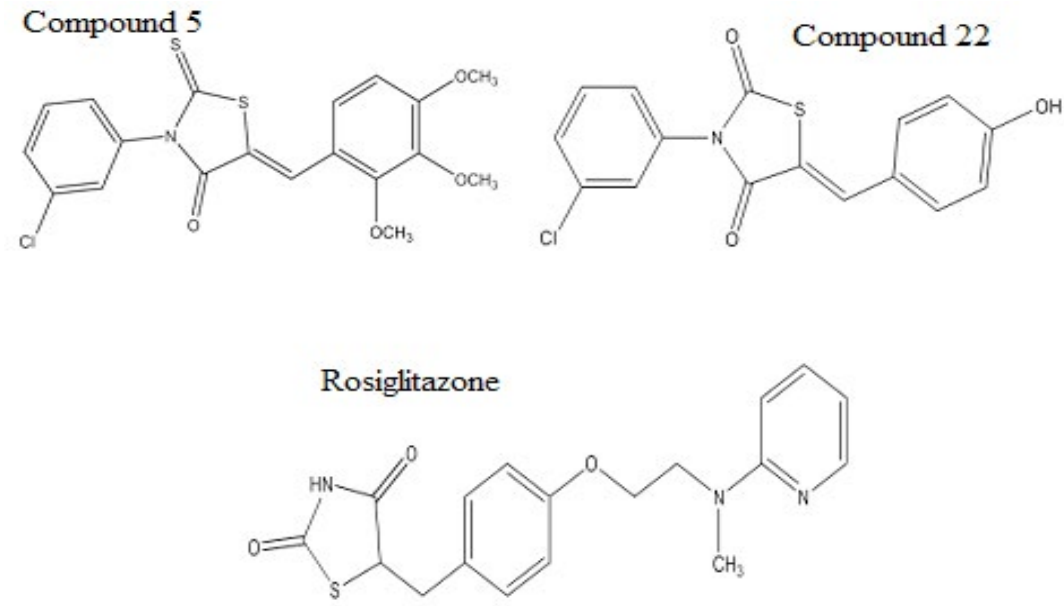

Figure 1. Strcture of the Novel glitazones and reference standard Rosiglitazone

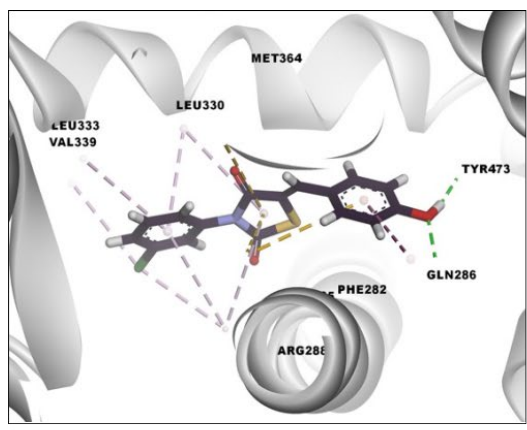

Compound-5 (C5) 3D

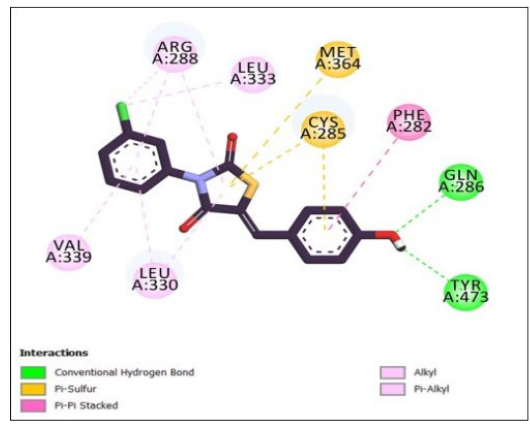

Compound-5 (C5) 2D

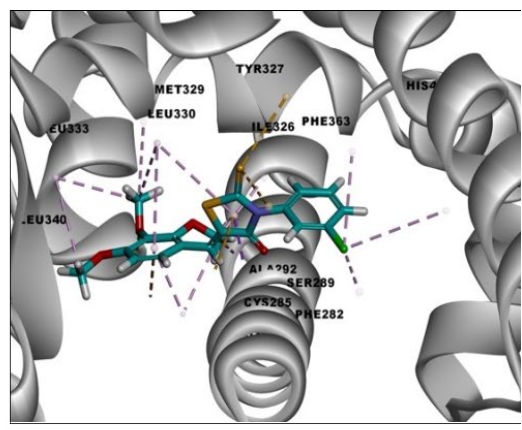

Compound-22 (C22) 3D

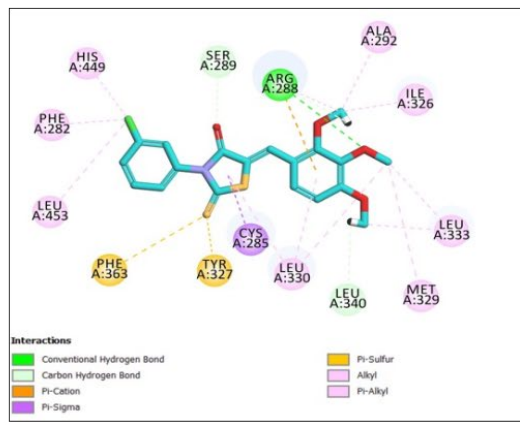

Compound-22 (C22) 2D

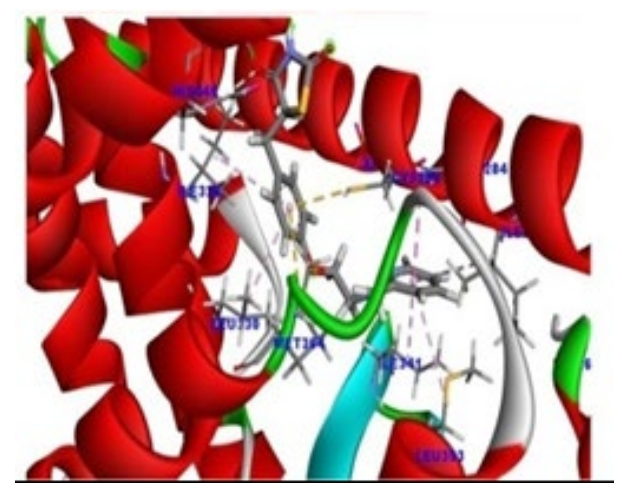

Standard Rosiglitazone

Figure 2.Molecular docking of novel glitazones legends and standard rosiglitazone 


\section{Acute oral toxicity test}

It was done in accordance to the OECD guideline 425 at one dose level of $300 \mathrm{mg} / \mathrm{kg}$ body weight and both the novel compounds ( $\mathrm{C} 5$ and $\mathrm{C} 22$ ) were not shown any mortality until 14 days. We considered $300 \mathrm{mg} / \mathrm{kg}$ as maximum tolerable dose and used 10 \& $20 \mathrm{mg} / \mathrm{kg}$ (less than 1/10 of the safe dose) for in-vivo hypoglycaemic activity.

\section{Body weight}

The body weight of all rats was assessed on $0^{\text {th }}$, $7^{\text {th }}, 14^{\text {th }}$ and $21^{\text {st }}$ day of study period. The control group exhibited the significant decrease in the body weight on day $14(201.25 \pm 12.69)$ and day 21 $(189.00 \pm 12.05)$ when compared to normal group.
Which shows significant induction of hyperglycemia in the animals. There was an increase in the body weight of treatment group of animals than the control group and compound $\mathrm{C} 5$ in both the doses showed better regain in the body weight than compound C22. Standard group showed significant increase in the body weight on day $14(247.12 \pm 14.75)$ and on day 21 (253.75 \pm 15.13$)$. The treatment groups at the dose 10 $\mathrm{mg} / \mathrm{kg} \mathrm{C5}(241.37 \pm 09.40), \mathrm{C} 22(234.00 \pm 11.12)$ and 20 $\mathrm{mg} / \mathrm{kg}$ C5 (246.37 \pm 08.11$)$, C22 (243.37 \pm 07.67$)$ were showed significant increase in body mass on day 21 when comapred with standard group $(253.75 \pm 15.13)$. The test compound C5 at a dose $10 \mathrm{mg} / \mathrm{kg}$ exhibited a significant increase in the body weight of animal than the $\mathrm{C} 22$ on day 21 (Figure 3).

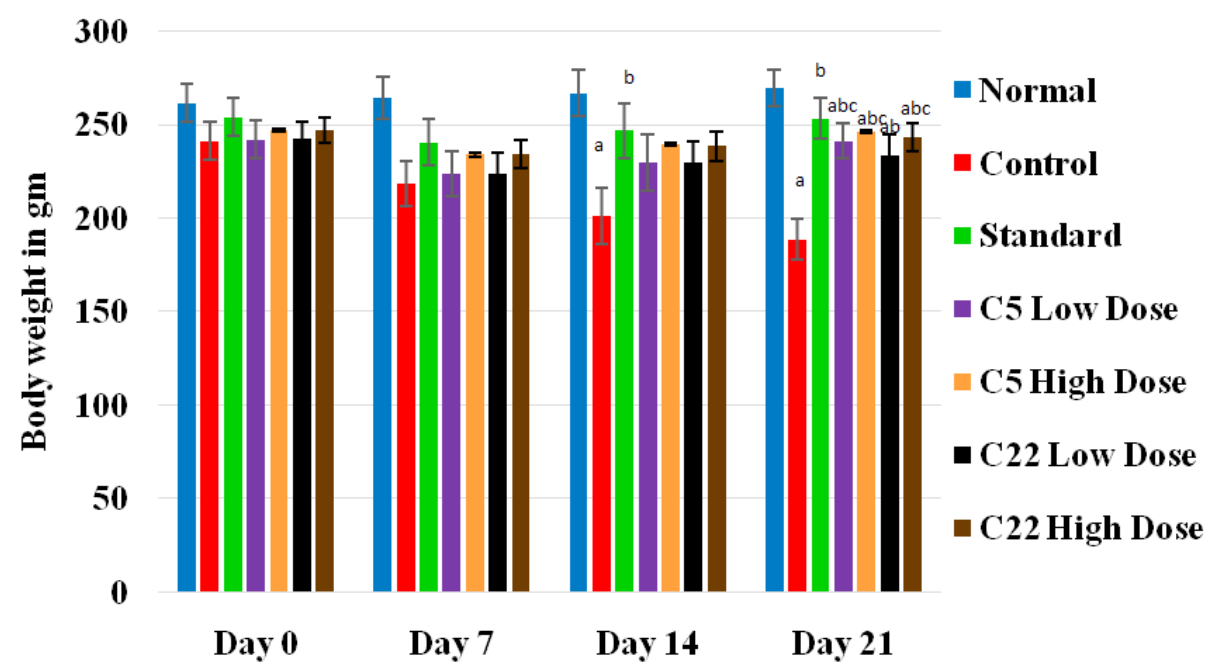

Figure 3. Protective effect of novel glitazones against STZ induced hyperglycaemic rat model

All the values are expressed as Mean \pm SEM, $n=8$.

The data were analysed by one-way ANOVA followed Tukey's multiple comparison test.

a-Significant when compared to the normal group $(p<0.05)$

$b$-Significant when compared to the control group $(p<0.05)$

$c$-Significant when compared to the standard group $(p<0.05)$

\section{Blood glucose level}

The blood glucose level of all rats was assessed on $0^{\text {th }}$, $7^{\text {th }}, 14^{\text {th }}$ and $21^{\text {st }}$ day of treatment period. The untreated (control) group of animals have shown the significant rise in the level of glucose on day $14(538.12 \pm 16.719)$ and $21(586.62 \pm 08.50)$ when compared to normal group. Which demonstrated significant induction of hyperglycemia. There was a significant decrease in the blood glucose level in treatment and standard group when compared with control group. Standard group showed significant decrease in the blood glucose level on day $14(259.37 \pm 19.74)$ and on day 21 (183.62 \pm 20.39$)$. The treatment groups at the dose 10 $\mathrm{mg} / \mathrm{kg} \mathrm{C5}$ (215.25 \pm 23.76$), \mathrm{C} 22(234.25 \pm 31.49)$ and 20

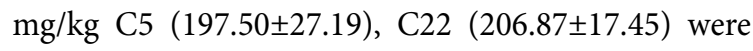
showed significant decrease in the glucose level on day 21. The test compound C5 at a dose of 10 and $20 \mathrm{mg} /$ $\mathrm{kg}$ exhibited a significant reduction in the glucose level than C22 on day21 (Figure 4). 


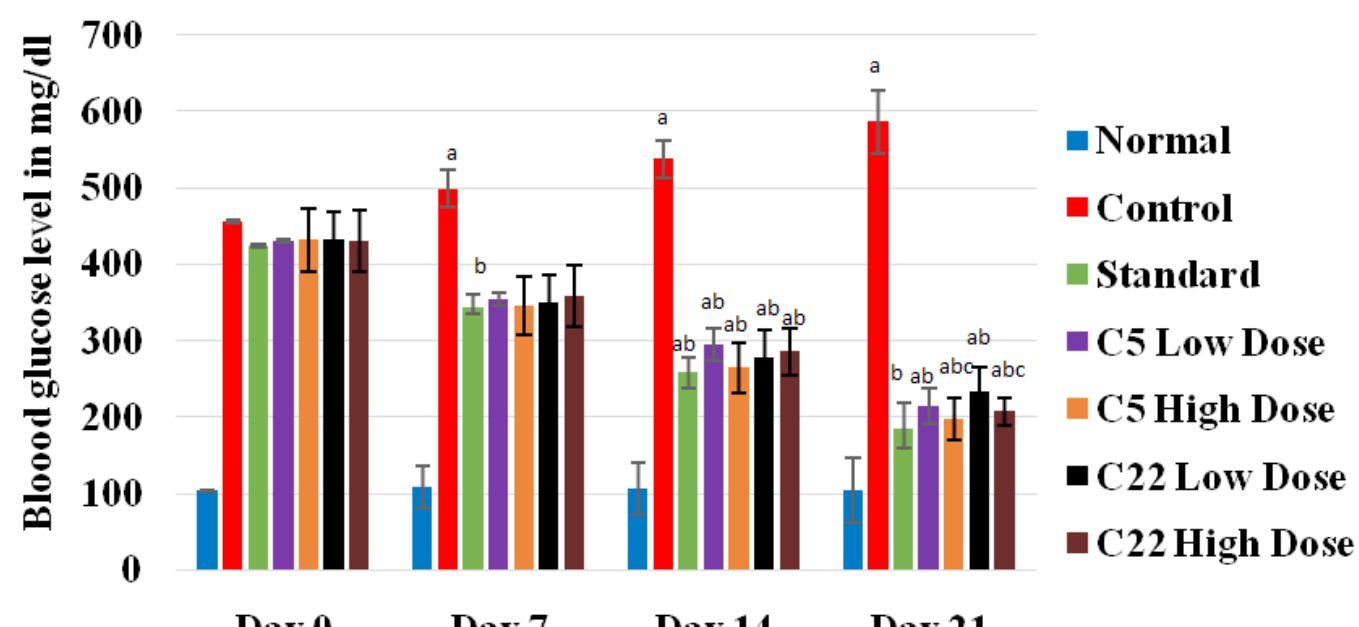

Figure 4. Protective effect of novel glitazones against STZ induced hyperglycaemic rat model All the values are expressed as Mean \pm SEM, $n=8$.

The data were analysed by one-way ANOVA followed Tukey's multiple comparison test.

$a$-Significant when compared to the normal group $(p<0.05)$

$b$-Significant when compared to the control group $(p<0.05)$

$c$-Significant when compared to the standard group $(p<0.05)$

\section{Serum lipid profile}

Control group of animals reported significant decrease in HDL levels when compared with normal group. Compare to control group, standard and C5 \& C22 treated groups have shown a significant rise in HDL level dose dependently but better rise in the
HDL level was observed in C5 group. The control group have shown increased level of LDL, TG and total cholesterol when compared with normal group. The treatment with novel compounds C5 \& C22 and standard have reversed the increased level; activity was observed at both doses and it was same as that of standard group of animals (Figure5).

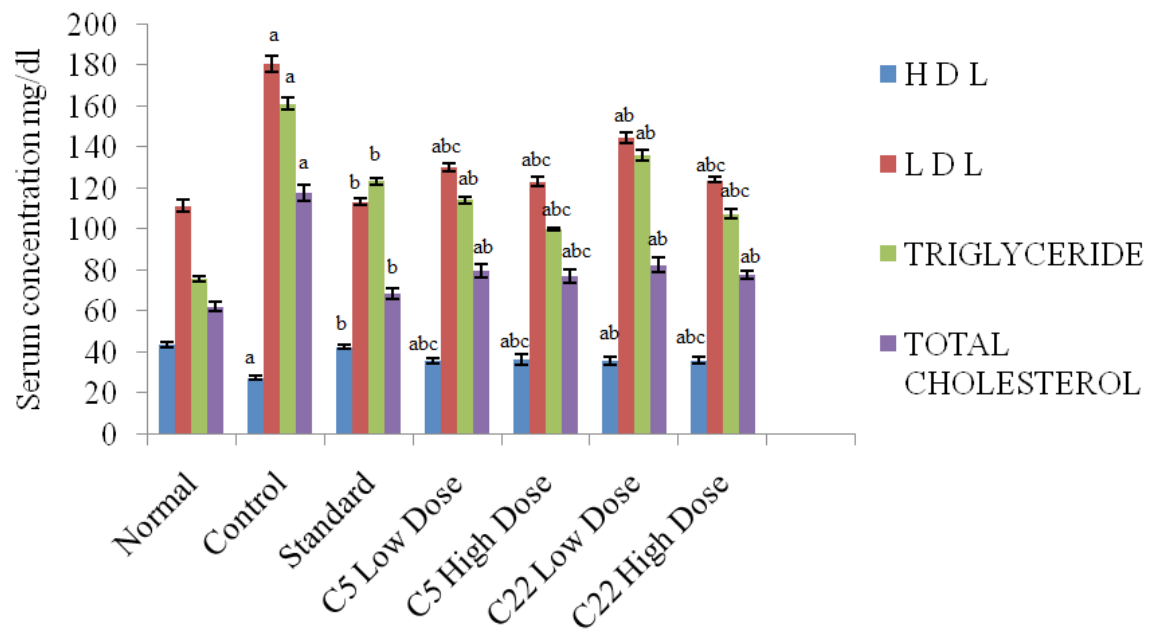

Figure 5. Protective effect of novel glitazones against STZ induced hyperglycaemic rat model

$$
\text { (Serum Lipid Profile) }
$$

All the values are expressed as Mean \pm SEM, $n=8$.

The data were analysed by one-way ANOVA followed Tukey's multiple comparison test.

a-Significant when compared to the normal group $(p<0.05)$

$b$-Significant when compared to the control group $(p<0.05)$

$c$-Significant when compared to the standard group $(p<0.05)$ 


\section{Liver enzyme profile- SGOT and SGPT}

SGOT and SGPT level in STZ control group showed a significant increase when comapred with normal group. SGOT and SGPT level was considerably decreased in the treatment group when compare to the control group and activity observed was dose dependent (Figure 6).

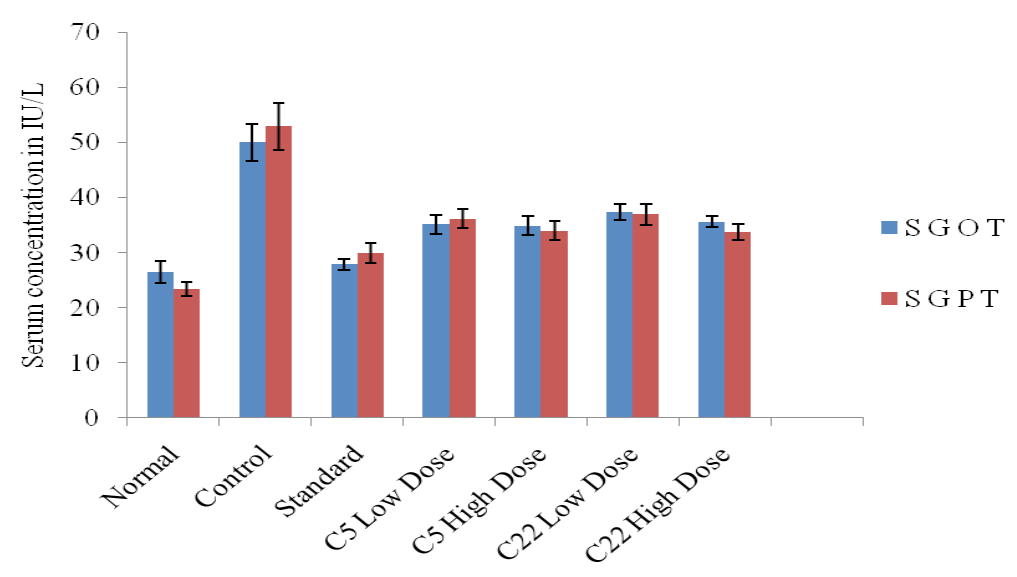

Figure 6. Protective effect of novel glitazones against STZ induced hyperglycaemic rat model (A-SGOT and B-SGPT)

All the values are expressed as Mean \pm SEM, $n=8$.

The data were analysed by one-way ANOVA followed Tukey's multiple comparison test.

a-Significant when compared to the normal group $(p<0.05)$

$b$-Significant when compared to the control group $(p<0.05)$

$c$-Significant when compared to the standard group $(p<0.05)$

\section{Histopathology of pancreas}

The effects of STZ on pancreas and its recovery from the treatment are depicted in the Figure 7. It was observed that, pancreas normal histology, Acini (AC), Islet of Langerhans (IL), Intercalated duct (ICD) and
Interlobular duct (ILD) are seen in the normal group of animals. The same is seen disturbed in STZ alone treated control group of animals, whereas damage of pancreas is reversed by the treatment with novel compound C5 and C22 as well as standard drug Figure 7.
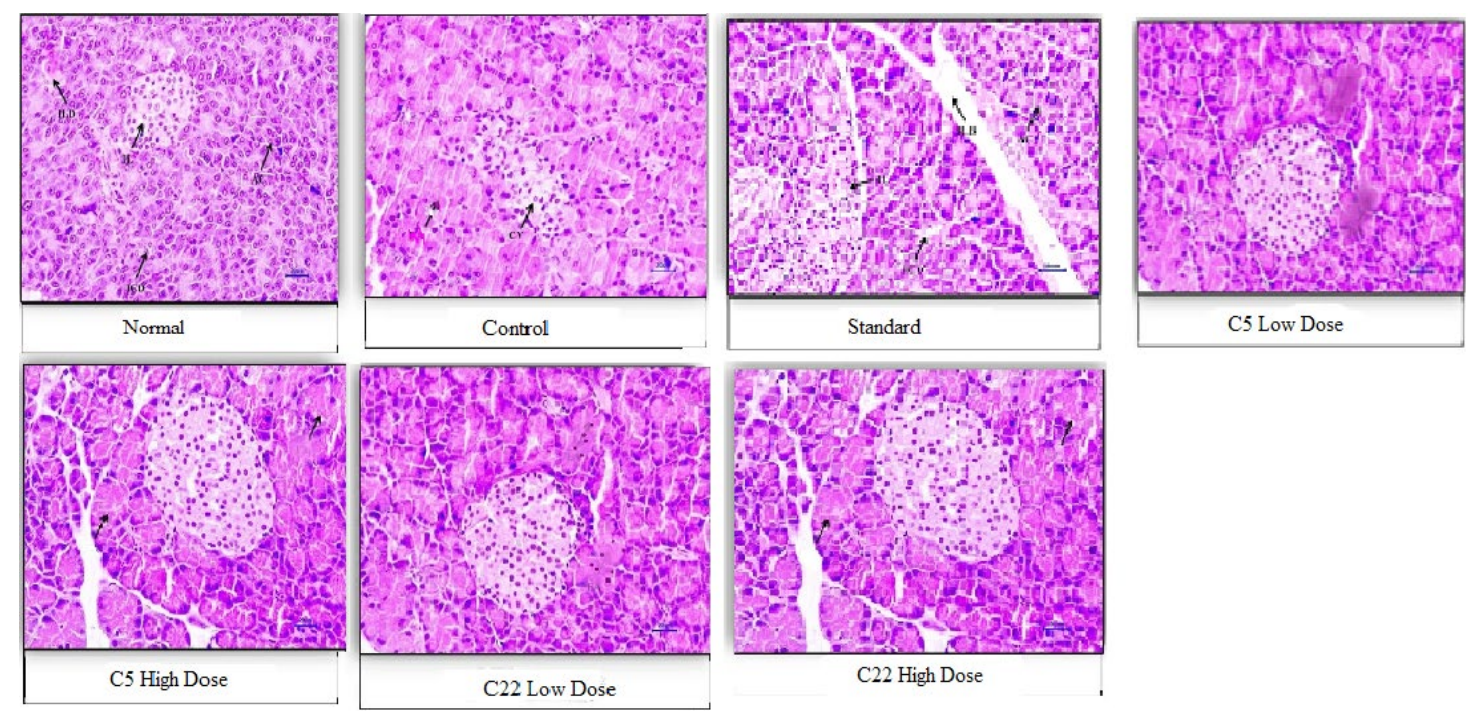

Figure 7. Protective effect of novel glitazones against STZ induced hyperglycaemic rat model 


\section{CONCLUSION}

The present investigation provides an evidence for protective effects of novel glitazone against STZ induced hyperglycemic rat model by the investigated parameters. The evaluation was done by morphological, biochemical and histopathological investigation. Both the novel glitazone had showed the hypoglycaemic activity dose dependently. The novel compound $\mathrm{C} 5$ had demonstrated good activity at both the doses whereas $\mathrm{C} 22$ at higher dose tested. The present investigation provides a lead for further studies required to support the present assumption and elucidate detailed protective action.

\section{ACKNOWLEDGEMENTS}

Authors are grateful to Principal, JSS College of Pharmacy, Mysuru and thanks to JSS Academy of Higher Education \& Research, Mysuru for providing necessary facilities required for our research work.

\section{CONFLICT OF INTEREST}

The authors declare that there is no conflict of interest.

\section{AUTHOR CONTRIBUTION STATEMENT}

Study conception, experimental design and exicustion (CHM). Project supervisor, study conception, experimental design and exicustion (KKL). Synthesised the virtual and physical novel compounds (PBR). Manuscript preparation, editing and assisting in the experimental works (SA). Manuscript preparation, editing and assisting in the experimental works (SD). Manuscript preparation, editing and assisting in the experimental works (SE). Manuscript preparation and editing (NHS). Manuscript preparation and editing. Cosupervising the project work (SM). Preparation of revised manuscript and editing (SS).

\section{REFERENCES}

Davis, S. (2012). Oral hypoglycaemic drugs for the treatment of type 2 diabetes mellitus. $S A$ Pharmaceutical Journal, 79(3), 22-26. DOI: 10.10520/EJC119715
Frier, B. M. (2014). Hypoglycaemia in diabetes mellitus: epidemiology and clinical implications. Nature Reviews Endocrinology, 10(12), 711-722. DOI: 10.1038/nrendo.2014.170

Graham, M. L., Janecek, J. L., Kittredge, J. A., Hering, B. J., Schuurman, H. J. (2011). The streptozotocin-induced diabetic nude mouse model: differences between animals from different sources. Comparative Medicine, 61(4), 356-360.

GraphPad Software LLC. (2020). GraphPad Prism 8 Statistics Guide - Welch and Brown-Forsythe ANOVA. Retrieved July 24, 2021, from https:// www.graphpad.com/guides/prism/latest/userguide/using_analyzing_data.htm

Lionta, E., Spyrou, G. K., Vassilatis, D., Cournia, Z. (2014). Structure-based virtual screening for drug discovery: principles, applications and recent advances. Current Topics in Medicinal Chemistry, 14(16), 1923-1938. DOI: 10.2174/156 8026614666140929124445

Lohning, A.E., M Levonis, S., Williams-Noonan, B., S Schweiker, S. (2017). A practical guide to molecular docking and homology modelling for medicinal chemists. Current Topics in Medicinal Chemistry, 17(18), 2023-2040. DOI: 10.2174/156 8026617666170130110827

Mal, S., Dwivedi, A. R., Kumar, V., Kumar, N., Kumar, B., Kumar, V. (2021). Role of Peroxisome Proliferator-Activated Receptor Gamma $(\operatorname{PPAR} \gamma)$ in Different Disease States: Recent Updates. Current Medicinal Chemistry, 28(16), 3193-3215. DOI: 10.2174/0929867327666200716 113136.

Meng, X. Y., Zhang, H. X., Mezei, M., Cui, M. (2011). Molecular docking: a powerful approach for structure-based drug discovery. Current Computer-aided Drug Design, 7(2), 146-157. DOI: 10.2174/157340911795677602 
Mohammed, F. Z., Gurigis, A. A., Abdel-Mageed, W. S., Nassr, A. (2018). Improvement of Insulin Sensitivity and Maintenance of Glucose Homeostasis in Insulin-sensitive Tissues via PPAR- $\gamma$ and Through Activation of PI3K/p-Akt Signaling Pathway by Resveratrol in Type 2 Diabetic Rats. Journal of Molecular Immunology, 3(119), 2. DOI: 10.21608/BLJ.2016.48169

Mukhtar, Y., Galalain, A., Yunusa, U. (2020). A modern overview on diabetes mellitus: a chronic endocrine disorder. European Journal of Biology, 5(2), 1-14. DOI: 10.47672/ejb.409

OECD (Organisation for Economic Cooperation and Development). (2008). Test No. 425: Acute Oral Toxicity: Up-and-Down Procedure. Test, (October), 1-21.
Yoshino, J., Baur, J. A., Imai, S. I. (2018). NAD+ intermediates: thebiologyand therapeutic potential of NMN and NR. Cell Metabolism, 27(3),513-528. DOI: 10.1016/j.cmet.2017.11.002

Zheng, Y., Ley, S. H., Hu, F. B. (2018). Global aetiology and epidemiology of type 2 diabetes mellitus and its complications. Nature Reviews Endocrinology, 14(2), 88-98. DOI: 10.1038/ nrendo.2017.151 